\title{
Hydrogeology of the Quitobaquito Springs and La Abra Plain Area, Organ Pipe Cactus National Monument, Arizona, and Sonora, Mexico
}

By R.L. Carruth

U.S. GEOLOGICAL SURVEY

Water-Resources Investigations Report 95-4295

Prepared in cooperation with the NATIONAL PARK SERVICE

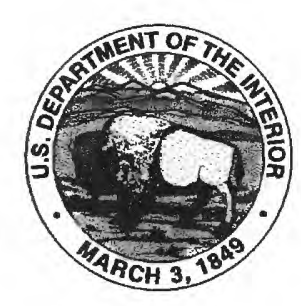




\title{
U.S. DEPARTMENT OF THE INTERIOR BRUCE BABBITT, Secretary
}

\author{
U.S. GEOLOGICAL SURVEY \\ Gordon P. Eaton, Director
}

For additional information write to:

\section{District Chief}

U.S. Geological Survey

Water Resources Division

375 South Euclid Avenue

Tucson, AZ 85719-6644
Copies of this report can be purchased from:
U.S. Geological Survey
Open-File Section
Box 25286, MS 517
Denver Federal Center
Denver, CO 80225 


\section{CONTENTS}

Abstract

Introduction

Purpose and scope

Geographic setting

Other investigations

Methods of investigation

Acknowledgments

Geologic units and their water-bearing properties

Granitic, metamorphic, and volcanic rocks.

Basin-fill deposits

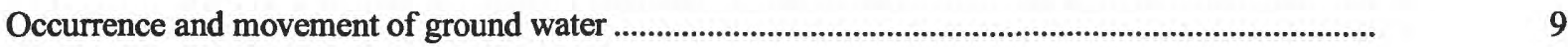

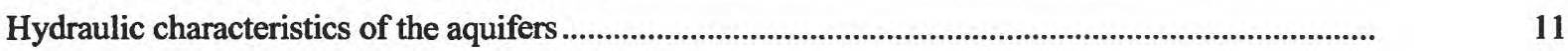

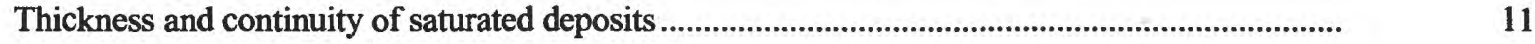

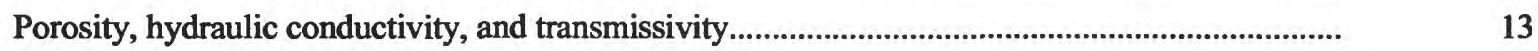

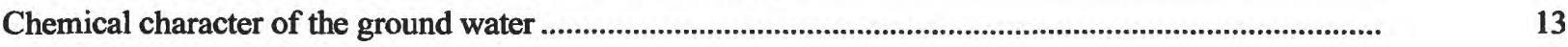

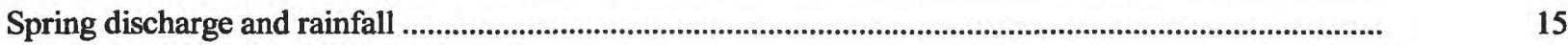

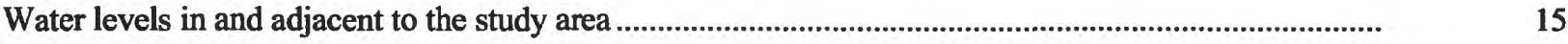

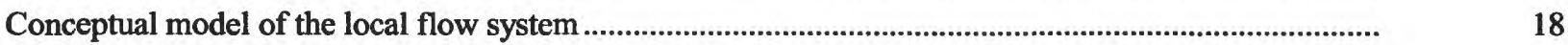

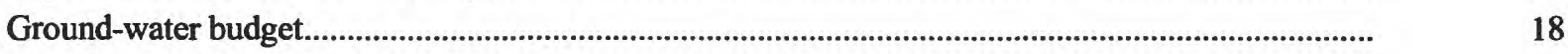

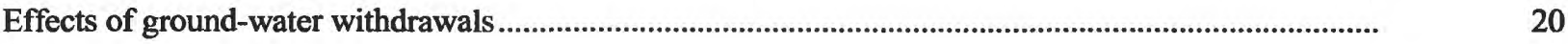

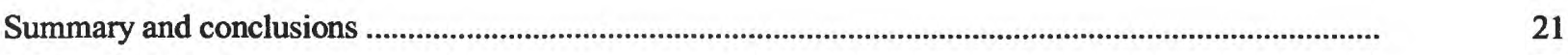

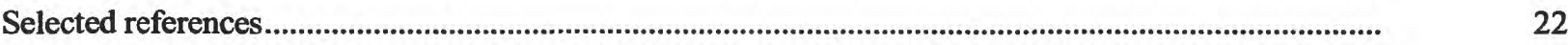

\section{FIGURES}

1-3. Maps showing:

1. Location of Quitobaquito Springs and La Abra Plain study area, Arizona, and Sonora, Mexico

2. Location of geophysical work in the Quitobaquito Springs and

La Abra Plain area, Arizona.

3. Geology of Quitobaquito Springs and La Abra Plain area, Arizona, and Sonora, Mexico

4. Schematic diagram showing a northeastward-trending hydrogeologic section through Quitobaquito Hills

5. Map showing estimated water-table altitude in the Quitobaquito Springs and

La Abra Plain area, Arizona, and Sonora, Mexico

6. Cross sections showing interpretation of boundaries between unsaturated and saturated deposits and consolidated rock on the basis of gravity and seismic data.

7. Trilinear diagram showing relative compositions of ground water in the Quitobaquito Springs and La Abra Plain area, Arizona, in equivalent percents 
8-10. Maps and graphs showing:

8. Total daily rainfall and mean monthly spring discharge in the Quitobaquito

Springs and La Abra Plain area, Arizona, 1981-92

9. Ground-water levels in the Quitobaquito

Springs and La Abra Plain area, Arizona, 1981-92.

10. Ground-water levels in the Lukeville area of Organ Pipe Cactus

National Monument, 1981-92

TABLES

1. Seismic-refraction data, Quitobaquito Springs and La Abra Plain area, Organ Pipe

Cactus National Monument, Arizona

\section{CONVERSION FACTORS}

\begin{tabular}{llll}
\hline Multlply & \multicolumn{2}{c}{ By } & To obtain \\
\hline inch (in.) & 25.40 & millimeter \\
foot $(\mathrm{ft})$ & 0.3048 & meter \\
square foot $\left(\mathrm{ft}^{2}\right)$ & 0.09290 & square meter \\
mile (mi) & 1.609 & kilometer \\
square mile $\left(\mathrm{mi}^{2}\right)$ & 2.590 & square kilometer \\
acre & 0.4047 & hectare \\
acre-foot $(\mathrm{acre}-\mathrm{ft})$ & 0.001233 & cubic hectometer \\
cubic foot $\left(\mathrm{ft}^{3}\right)$ & 0.02832 & cubic meter \\
foot per day per foot $[\mathrm{ft} / \mathrm{d}) / \mathrm{ft}]$ & 1 & meter per day per meter \\
foot squared per day $\left(\mathrm{ft}^{2} / \mathrm{d}\right)$ & 0.0920 & meter squared per day \\
gallon per minute $(\mathrm{gal} / \mathrm{min})$ & 0.06309 & liter per minute \\
\hline
\end{tabular}

In this report, air temperature is reported in degrees Fahrenheit $\left({ }^{\circ} \mathrm{F}\right)$, which can be converted to degrees Celsius $\left({ }^{\circ} \mathrm{C}\right)$ by the following equation:

$$
{ }^{\circ} \mathrm{C}=\left({ }^{\circ} \mathrm{F}-32\right) / 1.8
$$

\section{ABBREVIATED WATER-QUALITY UNITS}

Chemical concentrations are given only in metric units. Chemical concentration in water is given in milligrams per liter $(\mathrm{mg} / \mathrm{L})$. Milligrams per liter is a unit expressing the solute mass per unit volume (liter) of water. For concentrations less than 7,000 milligrams per liter, the numerical value is about the same as for concentrations in parts per million. 


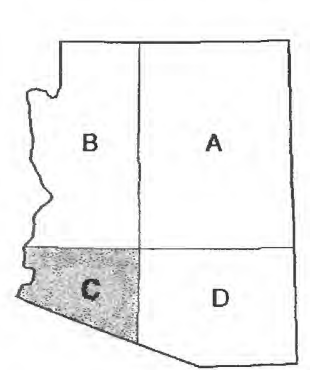

R. $8 \mathrm{E}$.

WELL (C-17-08)09add

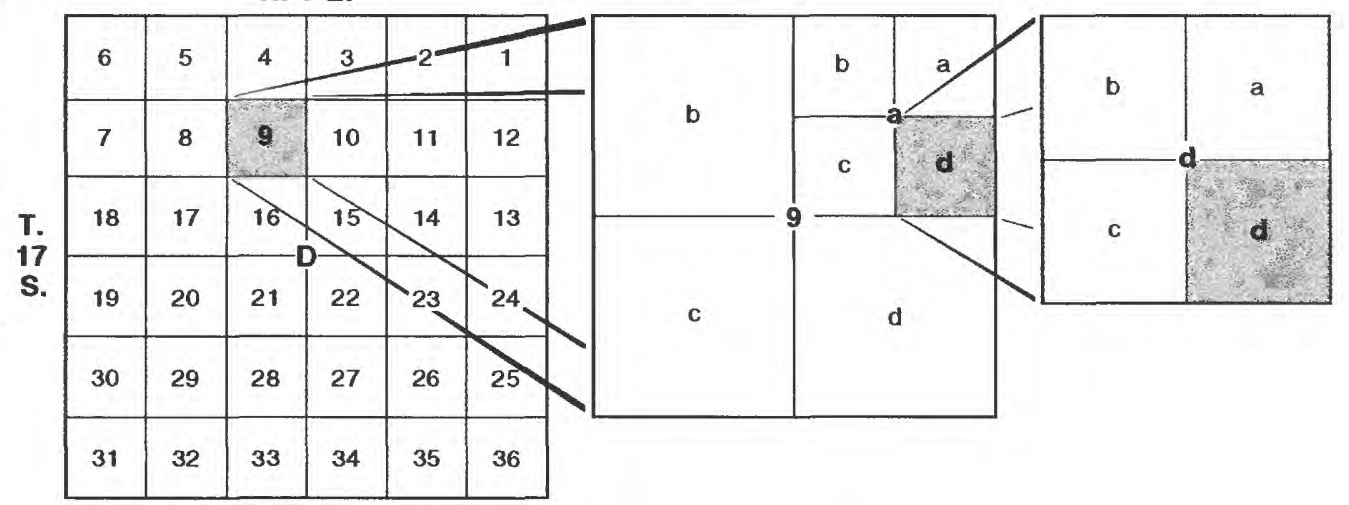

Quadrant C, Township 17 South, Range 8 East, section 9, quarter section a, quarter section $d$, quarter section $d$

The well numbers used by the U.S. Geological Survey in Arizona are in accordance with the Bureau of Land Management's system of land subdivision. The land survey in Arizona is based on the Gila and Salt River meridian and base line, which divide the state into four quadrants and are designated by capital letters A, B, C, and D in a counterclockwise direction, beginning in the northeast quarter. The first digit of a well number indicates the township, the second the range, and the third the section in which the well is situated. The lowercase letters a, b, c, and $d$ after the section number indicate the well location within the section. The first letter denotes a particular 160 -acre tract, the second the 40 -acre tract and the third the 10-acre tract. These letters also are assigned in a counterclockwise direction, beginning in the northeast quarter. If the location is known within the 10-acre tract, three lowercase letters are shown in the well number. Where more than one well is within a 10 -acre tract, consecutive numbers beginning with 1 are added as suffixes. In the example shown, well number (D-13-11)18ddd designates the well as being in the SE1/4, SE1/4, SE1/4, section 18, Township 13 South, and Range 11 East.

\section{VERTICAL DATUM}

Sea level: In this report, "sea level" refers to the National Geodetic Vertical Datum of 1929-A geodetic datum derived from a general adjustment of the first-order level nets of the United States and Canada, formerly called Sea Level Datum of 1929. 


\title{
Hydrogeology of the Quitobaquito Springs and La Abra Plain Area, Organ Pipe Cactus National Monument, Arizona, and Sonora, Mexico
}

\author{
By R.L. Carruth
}

\section{Abstract}

Quitobaquito Springs, in Organ Pipe Cactus National Monument near the south end of the northwestward-trending Quitobaquito Hills, are less than 0.25 mile north of the international boundary between the United States and Mexico. The National Park Service is concerned that the natural flow from Quitobaquito Springs might be reduced by ground-water withdrawals in the adjacent State of Sonora, Mexico.

Quitobaquito and other nearby springs flow from a highly fractured granite that forms the Quitobaquito Hills. Fractures in the granitic intrusive rocks provide conduits for ground water to flow from an alluvial flow system along Aguajita Wash to a line of springs on the southwest side of Quitobaquito Hills. The chemical composition of water from all the springs is similar. Carbon-14 analysis of water from Quitobaquito Springs indicates that the spring water probably is between 500 and several thousand years old. Discharge at Quitobaquito Springs averaged 28 gallons per minute and ranged from 15 to 40 gallons per minute for 1981-92. Rainfall at two gages in the area of recharge to the northeast of Quitobaquito Hills averaged 6.6 inches per year during the 11-year monitoring program ending in September 1992. The lack of correlation between spring discharge and local rainfall indicates that local annual recharge may be small relative to the total quantity of ground water in storage.

Surface-geophysical data indicate that a thin alluvial aquifer overlies the shallow crystalline rocks northeast of Quitobaquito Hills along Aguajita Wash. Results of the study indicate that the ground-water flow system along Aguajita Wash provides a source of water to the springs and may be hydraulically connected to the ground-water system that is pumped for agricultural purposes in Mexico. The altitude and low permeability of the granite bedrock near the international boundary, however, may provide a barrier to and (or) delay the effect of a northwestward propagation of water-level declines caused by pumping near the Rio Sonoyta in Mexico.

\section{INTRODUCTION}

The Quitobaquito Springs and La Abra Plain study area encompasses about $100 \mathrm{mi}^{2}$ in Organ Pipe Cactus National Monument, Arizona, and north-central Sonora, Mexico (fig. 1). The climate is arid to semiarid. The climate and available ground water provide favorable conditions for irrigated agriculture south of the Organ Pipe
Cactus National Monument along the Rio Sonoyta in Mexico. Ground water is being withdrawn from about $30 \mathrm{mi}$ east to about $5 \mathrm{mi}$ west of the springs and within $1 \mathrm{mi}$ south of the springs. Quitobaquito Springs, two of several springs near the south end of the northwestward-trending Quitobaquito Hills, are less than $0.25 \mathrm{mi}$ north of the international boundary. Quitobaquito Springs and the adjacent pond are habitat of the endangered desert pupfish 
(Cyprinidon macularius eremus). The U.S. Geological Survey (USGS), in cooperation with the National Park Service, began a study of the hydrogeologic characteristics of the Quitobaquito Springs and La Abra Plain area to determine if natural flow from Quitobaquito Springs could be reduced by ground-water withdrawals in the adjacent State of Sonora, Mexico.

\section{Purpose and Scope}

This report describes the hydrologic system of the study area, particularly the ground-water flow system that provides water to the springs, and the physical constraints of this flow system. Descriptions are presented for the rock units that form the boundaries of the study area, provide a surface for mountain-front recharge, and influence the flow of ground water in the basin-fill deposits and to the springs. The chemical character of the ground water is described to provide additional information on ground-water flow patterns as related to changes in water chemistry and to evaluate the age and probable source of the ground water. A conceptual model of the aquifer system and movement of ground water was developed. Estimates of the ground-water budget were made to provide additional conceptual information on the amount of ground water that enters, leaves, and is stored within the ground-water flow system that provides water to the springs. An evaluation was made about the possibility that discharge at the springs could be reduced by ground-water withdrawals south of the international boundary on the basis of data from the monitoring program, chemical analyses, and geophysical investigations.

\section{Geographic Setting}

The study area consists of the Quitobaquito Springs and La Abra Plain area in Arizona, and Sonora, Mexico. Most of the La Abra Plain area, including Quitobaquito Springs, is north of the international boundary and within the Organ Pipe Cactus National Monument. The study area is bounded on three sides by mountains within the monument and by the Rio Sonoyta in Mexico. La Abra Plain is an alluvial plain or bajada that extends from the base of the mountain fronts and slopes to the southwest toward the Rio Sonoyta Valley in Mexico. Many ephemeral streams originate in the mountains adjacent to La Abra Plain and are tributary to the ephemeral Rio Sonoyta. Aguajita Wash is the largest ephemeral tributary and is near the base of the mountain fronts in the western part of La Abra Plain. The mountains in the study area rise from about 1,100 to $3,100 \mathrm{ft}$ above sea level, and the valley floor ranges in altitude from 1,000 to $1,600 \mathrm{ft}$ above sea level.

\section{Other Investigations}

Geologic, hydrologic, and geochemical studies by several investigators were helpful in evaluating the hydrogeology of the study area. To improve the understanding of the hydrogeology of the Quitobaquito Springs area, the USGS, in cooperation with the National Park Service, began a reconnaissance study in 1976 (T.W. Anderson and R.L. Laney, hydrologists, USGS, written commun., 1978). Findings of the reconnaissance study greatly improved knowledge of the hydrogeology of the area; however, the ground-water flow system that provides a source of water to the springs was not defined because of the lack of hydrologic data. The reconnaissance study resulted in a program beginning in 1981 to monitor discharge at Quitobaquito Springs, rainfall in areas upgradient from the springs, and ground-water levels in the study area and adjacent areas in the monument near the international boundary (T.W. Anderson and R.L. Laney, hydrologists, USGS, written commun., 1978). Conclusions reached by Anderson and Laney (USGS, written commun., 1978) were used to plan the surface geophysical surveys for this study by identifying areas where additional data were needed. Hydrologic investigations by Hollett (1985) and Hollett and Marie (1987) in other alluvial basins with hydrogeologic characteristics similar to the study area were used in making estimates of hydraulic properties of the local aquifer system. A study by Robertson (1991) was used to describe the relation between the chemical character of the water from Quitobaquito Springs and two wells in the study area. 


\section{Methods of Investigation}

On the basis of previous investigations, areas of sparse or missing data were identified and a program of fieldwork was started in 1992 that included surface geophysical surveys and water-level measurements on both sides of the international boundary. Existing water-chemistry, water-level, spring-discharge, and rainfall data were compiled and analyzed. Information on the surface geology and the structure of the study area was compiled from published reports and maps. Reconnaissance geologic mapping was done where existing data were too generalized. Interpretations were made on the basis of the interdependence of geological, hydrological, geophysical and waterchemistry data.

Approximately 95 percent of Organ Pipe Cactus National Monument is designated as wilderness area; thus, to obtain information about the subsurface units that control the location, extent, and movement of ground water in the study area and specifically to the springs, surface geophysical surveys were done using several noninvasive methods (fig. 2). Gravity measurements were made along the perimeter roads in $\mathrm{La}$ Abra Plain and east of Quitobaquito Hills to approximate the depth to bedrock. Gravity stations were located using a global-positioning system (GPS). Seismic-refraction techniques were used to further assess the hydrogeologic framework and to provide a source of control for the gravity-data analysis. Seismic-refraction techniques were used in areas of specific interest, identified by gravity data and geologic mapping, to estimate depth to water, thickness of the saturated material, and depth to bedrock.

Chemical analyses of water samples collected in 1976 from Bonita Well, Pozo Salado Well, and Quitobaquito Springs were re-evaluated with additional laboratory analyses of samples collected at the three sites in 1983 by the USGS. The chemical compositions of the samples were compared with Robertson's (1991) findings for the compositions of ground water in alluvial basins of Arizona. A carbon-14 analysis of the water sample collected in 1983 from Quitobaquito Springs was done to determine the relative age of the water.
Data from an 11-year program of monitoring spring discharge, rainfall, and water levels in and adjacent to the study area were analyzed to determine the relation among rainfall, springflow, and water levels. Additional fieldwork in the study area included measuring water levels, obtaining accurate measuring-point altitudes with GPS, and estimating pumping capacities of several wells in the agricultural area along the Rio Sonoyta in Mexico.

\section{Acknowledgments}

Jim Barnett and personnel of Organ Pipe Cactus National Monument provided information from monument data bases, provided assistance in field operations, and made housing available at the monument during the study. James B. Fink, HydroGeophysics Inc., provided technical assistance and assistance during field operations. The Secretario de Agriculturia y Recursos Hidraulicos provided water-level data for the part of the study area in Mexico.

\section{HYDROGEOLOGY}

Quitobaquito Springs and La Abra Plain are in the Basin and Range physiographic province (Fenneman, 1931), which is characterized by long, narrow mountain ranges separated by broad alluvium-filled valleys that contain ground water. Tectonism of the Basin and Range disturbance involved the relative movement of crustal blocks to form a complex system of subsidence structures that blocked out the northward- and northwestward-trending mountain ranges and became the sediment-filled basins (Damon and others, 1984).

The Quitobaquito Hills, Puerto Blanco Mountains, and Sonoyta Mountains consist mainly of Mesozoic crystalline rocks that were exposed by thrust faulting and tectonic sliding that occurred during the late Cretaceous and early Tertiary periods (Haxel and others, 1984; fig. 3, this report). The Cipriano Hills are composed mainly of extrusive volcanic rocks with small amounts of sedimentary rocks of the Tertiary period (Gray and others, 1988). La Abra Plain is underlain by 
Tertiary and Quaternary basin-fill deposits that consist of unconsolidated to weakly consolidated gravel, sand, and silt (Anderson and others, 1992). The ephemeral stream channels in the study area contain unconsolidated gravel and sand. Surficial alluvial deposits mantle crystalline-rock pediments east of Quitobaquito Hills and probably near the other mountains in the study area (T.W. Anderson and R.L. Laney, USGS, written commun., 1978).

\section{Geologic Units and Their Water-Bearing Properties}

The granitic, metamorphic, and extrusive volcanic rocks that surround the study area store and transmit smaller quantities of water than the more porous and hydraulically conductive basin-fill deposits. Granitic and metamorphic rocks generally have the lowest hydraulic conductivities; however, the highly fractured granite in and near the Quitobaquito Hills transmits small to moderate quantities of water to springs. Hydraulic conductivity of the extrusive volcanic rocks probably is highly variable and dependent on the development of interconnecting fractures and the amount of interflow brecciation. In addition to storing and transmitting small quantities of water, the rocks structurally control the flow of ground water in the basin-fill deposits and to the springs.

\section{Granitic, Metamorphic, and Volcanic Rocks}

Crystalline rocks of Mesozoic and Early Tertiary age are exposed in the Quitobaquito Hills, Puerto Blanco Mountains, and Sonoyta Mountains that surround La Abra Plain to the southwest, northeast, and east, respectively. The principal lithologic types are granite gneiss, schist, granite, and locally some metamorphic rocks of volcanic and sedimentary origin (Gray and others, 1988). The highly fractured granite, which forms the Quitobaquito Hills and adjacent outcrops, transmits ground water from the alluvial deposits along Aguajita Wash (fig. 4) to a line of springs on the southwest side of Quitobaquito Hills and to Aguajita Spring. A northwestward-trending highangle fault mapped by Haxel (1984) on the southwest side of Quitobaquito Hills may control the location of the springs. The extent of the fracture system within the granitic rocks and the permeability of the fractures are not known.

Volcanic rocks in and adjacent to the study area range in composition from basalt to rhyolite. Northwest of La Abra Plain, volcanic rocks of Tertiary age are exposed in the Cipriano Hills. The Cipriano Hills contain some minor vents and oxidized cinder-cone deposits and are composed mainly of basaltic andesite extrusive rocks that are between 16 million and 14 million years old (Gray and others, 1988). Tuff, welded tuff, volcanic-flow breccia, and agglomerate occur locally in and near the Cipriano Hills. The volcanic rocks may store and transmit small to moderate quantities of water. Data are not available on the water-bearing characteristics of the volcanic rocks in the study area; however, at the Organ Pipe Cactus National Monument headquarters approximately $10 \mathrm{mi}$ east of the study area, several wells are completed in the volcanic rocks and produce as much as $30 \mathrm{gal} / \mathrm{min}$ of water.

\section{Basin-Fill Deposits}

Basin-fill deposits include the unconsolidated to weakly consolidated gravel, sand, and silt that fill the La Abra Plain area between the mountains and cover the pediments on the lower slopes. Basin fill was deposited as overlapping and interconnecting lenses of slope wash and alluvium along the mountain fronts. Lenses of boulders, gravel, sand, and silt generally grade away from the mountain slope toward the basin center to alluvial-fan and stream-channel deposits that define the La Abra Plain area. Alluvial-fan sediments are less permeable than stream-channel deposits.

La Abra Plain is an alluvial plain or bajada that extends from the base of the mountain fronts and slopes downward toward the Rio Sonoyta Valley in Mexico. Gravity data indicate that depth to bedrock increases toward the basin center, and previous studies indicate that the basin fill may be as much as $1,000 \mathrm{ft}$ thick near the center of the basin. The basin fill is interrupted by local bedrock outcrops near the basin margins that are exposed through the basin fill. 


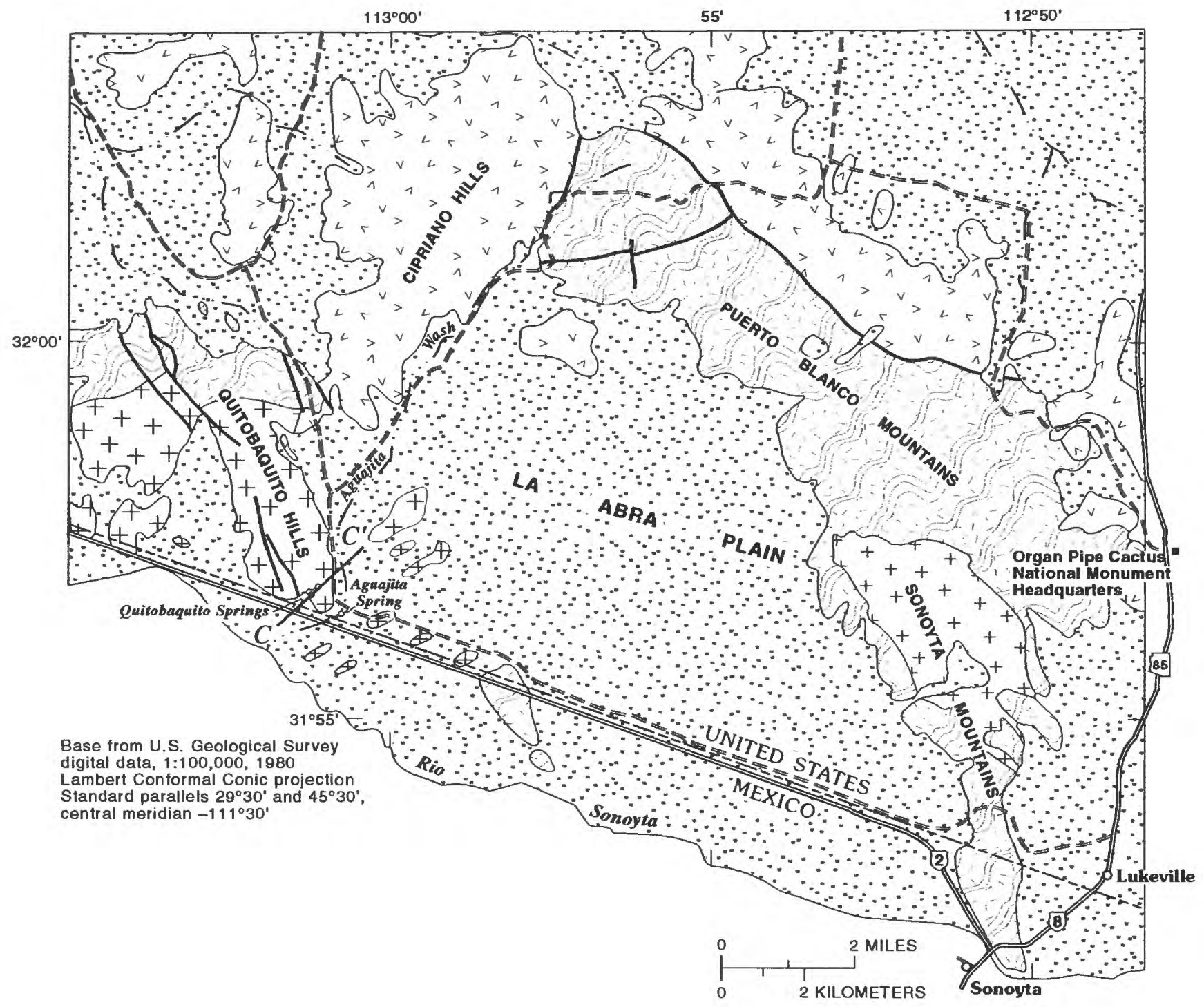

EXPLANATION

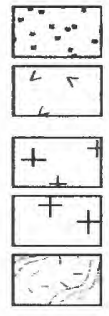

ALLUVIUM (QUATERNARY AND LATE TERTIARY)
VOLCANIC AND SEDIMENTARY ROCKS (LATE
TERTIARY)
GRANITE (EARLY TERTIARY)
GRANITE (LATE CRETACEOUS)
VARIABLY METAMORPHOSED MESOZOIC CRYS-
TALLINE ROCKS (JURASSIC, CRETACEOUS,
AND EARLY TERTIARY) Includes granite gneiss,
schist, granite, and locally some dark finely crystal-
line granite porphyry derived from volcanic and
sedimentary rocks

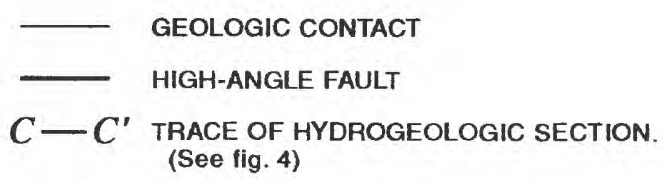

Figure 3. Geology of Quitobaquito Springs and La Abra Plain area, Arizona, and Sonora, Mexico (modified from Gray and others, 1988). 


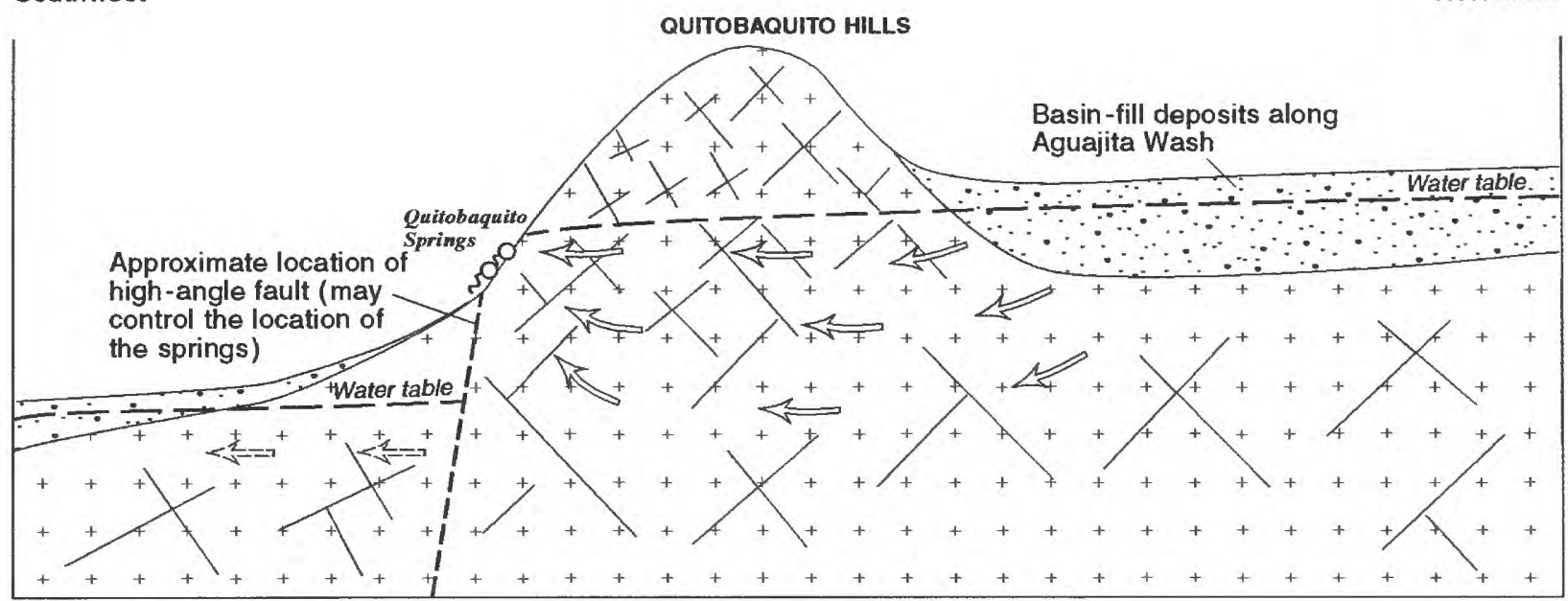

VERTICAL SCALE GREATLY EXAGGERATED

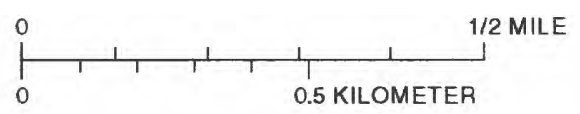

EXPLANATION

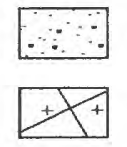

ALLUVIUM (QUATERNARY AND LATE
TERTIARY)

FRACTURED GRANITIC ROCKS (LATE CRETACEOUS)

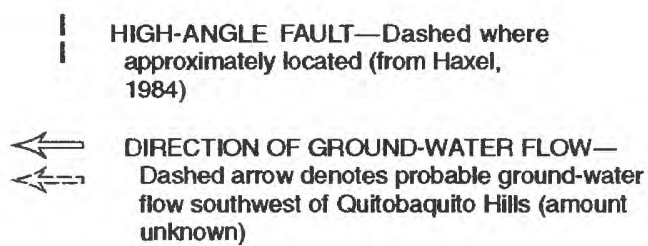

IGH-ANGLE FAULT-Dashed where approximately located (from Haxel,

DIRECTION OF GROUND-WATER FLOWflow southwest of Quitobaquito Hills (amount unknown)

Figure 4. Schematic diagram showing a northeastward-trending hydrogeologic section through Quitobaquito Hills. (Trace of section shown in fig. 3.)

Information is scant on the water-bearing characteristics of the basin fill in the study area. North of the international boundary, two hand-dug wells penetrate the basin fill (fig. 1). Bonita Well, finished to a depth of $36 \mathrm{ft}$, is completed in the basin-fill deposits near Aguajita Wash in the upper part of the ground-water-flow system. Pozo Salado Well, finished to a depth of $111 \mathrm{ft}$, is completed in the basin-fill deposits near the center of La Abra Plain. In December 1976, Bonita Well and Pozo Salado Well produced 1.5 and $2.0 \mathrm{gal} / \mathrm{min}$ of water, respectively (T.W. Anderson and R.L. Laney, USGS, written commun., 1978). Anderson and Laney stated that these discharges probably represented only the capacity of the windmill pump at each well at the time of measurement. The basin-fill deposits at these sites probably are capable of yields many times greater than the measured discharges.

Several ephemeral stream channels originate in the adjacent mountains and terminate at the Rio Sonoyta in Mexico. Stream-channel deposits occur as narrow bands of alluvium deposited in incised channels within the less permeable basin-fill deposits. These deposits were created by highvelocity streamflow and contain unconsolidated boulders, gravel, and sand. Less permeable fan sediments deposited by sheetflow typically surround stream-channel deposits.

Several wells were visited in the study area south of the international boundary (fig. 5). Discharges for agricultural wells near the Rio Sonoyta ranged from several tens of gallons per minute for a well in Cerro Colorado to several hundreds of gallons per minute for a well in Santo Domingo. 
These wells probably are completed in the stream-channel deposits of the Rio Sonoyta.

\section{Occurrence and Movement of Ground Water}

The ground-water basin of the La Abra Plain area encompasses approximately $100 \mathrm{mi}^{2}$ and is defined by the surrounding mountains to the southwest, northeast, and east, and by the Rio Sonoyta to the south (fig. 5). Water-level, geophysical, and water-chemistry data indicate that ground-water flow parallels the direction of surface-water drainage in at least the west half of the study area. In addition, data indicate that a local flow system exists along the Aguajita Wash drainage and provides a source of water to the springs (fig. 5). The largest continuous body of saturated basin-fill deposits probably exists in the central part of La Abra Plain and extends south of the international boundary to the Rio Sonoyta.

Ground water occurs primarily in the basin-fill and stream-channel deposits under unconfined or water-table conditions. Ground water also occurs in the fractured granitic rocks, as evidenced by the springs, and probably in the volcanic and metamorphic rocks. Depth to water ranges from about $25 \mathrm{ft}$ in Bonita Well near the upper reaches of the flow system to greater than $93 \mathrm{ft}$ in Pozo Salado Well near the center of the basin. Depth to water ranges from 20 to $40 \mathrm{ft}$ in wells near the Rio Sonoyta.

Water-level data were insufficient to construct a detailed water-table altitude map for the entire study area; however, a water-table map of the western and southern parts of the area is shown in figure 5 and was based on measured water levels, spring-discharge altitudes (Brian Goodman, University of Arizona, written commun., 1993), and interpreted seismic-refraction data (table 1 and fig. 5). For the agricultural area south of the international boundary, water-table altitudes are based on measured water levels in wells and on water-level data from agencies in Mexico (Secretario de Agriculturia y Recursos Hidraulicos, written commun., 1993).

Ground water moves in the direction of decreasing hydraulic head from areas of inflow to the outflow line of the basin along the Rio Sonoyta. In the study area, ground water probably moves through the basin fill in a southward to southwestward direction toward the Rio Sonoyta in Mexico. Ground water also moves through the well-fractured granite and is discharged in the line

Table 1. Seismic-refraction data, Quitobaquito Springs and La Abra Plain area, Organ Pipe Cactus National Monument, Arizona

[Dashes indicate depth to consolidated rock is greater than the range of the survey; $\geq$, greater than or equal to; $\leq$, less than or equal to]

\begin{tabular}{|c|c|c|c|c|c|c|c|c|c|}
\hline \multirow[b]{2}{*}{$\begin{array}{l}\text { Llne } \\
\text { number }\end{array}$} & \multicolumn{3}{|c|}{ Layer 1-Unsaturated basin fill } & \multicolumn{3}{|c|}{ Layer 2-Saturated basin fill } & \multicolumn{3}{|c|}{ Layer 3-Consolldated rock } \\
\hline & $\begin{array}{l}\text { Depth } \\
\text { below } \\
\text { land } \\
\text { surface, } \\
\text { In feet }\end{array}$ & $\begin{array}{l}\text { Eleva- } \\
\text { tlon, } \\
\text { in feet }\end{array}$ & $\begin{array}{l}\text { Average } \\
\text { velocity, } \\
\text { In feet per } \\
\text { second }\end{array}$ & $\begin{array}{l}\text { Depth } \\
\text { below } \\
\text { land } \\
\text { surface, } \\
\text { In foet }\end{array}$ & $\begin{array}{l}\text { Eleva- } \\
\text { tlon, } \\
\text { in feet }\end{array}$ & $\begin{array}{l}\text { Average } \\
\text { veloclty, } \\
\text { In feet per } \\
\text { second }\end{array}$ & $\begin{array}{l}\text { Depth } \\
\text { below } \\
\text { land } \\
\text { surface, } \\
\text { In foet }\end{array}$ & $\begin{array}{l}\text { Eleva- } \\
\text { tlon, } \\
\text { in feet }\end{array}$ & $\begin{array}{c}\text { Average } \\
\text { velocity, } \\
\text { In feet per } \\
\text { second }\end{array}$ \\
\hline 1 & 0 & 1,350 & 2,064 & 20 & 1,330 & 8,895 & -- & $-\cdots$ & ---- \\
\hline 2 & 0 & 1,115 & 1,622 & 34 & 1,081 & 11,538 & - & - & $-\ldots$ \\
\hline 3 & 0 & 1,115 & 1,318 & 12 & 1,103 & 3,102 & 43 & 1,072 & 18,762 \\
\hline 4 & 0 & 1,190 & 2,711 & 34 & 1,156 & 6,762 & $\geq 180$ & $\leq 1,010$ & ${ }^{\prime} 18,000$ \\
\hline 5 & 0 & 1,190 & 2,456 & 53 & 1,137 & 7,686 & $\geq 140$ & $\leq 1,050$ & ${ }^{\prime} 18,000$ \\
\hline 6 & 0 & 1,160 & 2,398 & 29 & 1,131 & 8,440 & $\geq 90$ & $\leq 1,070$ & ${ }^{1} 18,000$ \\
\hline 7 & 0 & 1,168 & 1,443 & 21 & 1,147 & 9,450 & 106 & 1,062 & 25,000 \\
\hline 8 & 0 & 1,165 & 1,245 & 16 & 1,148 & 7,956 & 75 & 1,090 & 13,333 \\
\hline 9 & 0 & 1,132 & 1,445 & 18 & 1,114 & 9,207 & 75 & 1,057 & 18,286 \\
\hline
\end{tabular}

'Assumed velocity value to enable minimum depth calculation. 
of springs on the southwest side of the Quitobaquito Hills.

In the La Abra Plain area, all ground water probably originates as rainfall. Recharge occurs primarily from infiltration of overland flow along the mountain fronts and through the streamchannel deposits. Most of the infiltration probably occurs through the alluvial deposits that cover the shallow crystalline rocks along the mountain fronts.

In the west half of the study area between Bonita Well and Aguajita Spring, water levels and geophysical data indicate that the gradient of the water table is about $0.008 \mathrm{ft} / \mathrm{ft}$. This gradient probably represents conditions of the local flow system along Aguajita Wash. The gradient decreases to about $0.0009 \mathrm{ft} / \mathrm{ft}$ south of the international boundary. Data are insufficient to determine the water-table gradient for the aquifer in the central part of the basin.

\section{Hydraulic Characteristics of the Aquifers}

The hydraulic characteristics of the aquifers in the study area affect the rate at which water moves through the aquifers, the flow to the springs, the amount of water in storage, and the rate and areal extent of water-level declines caused by ground-water withdrawals south of the international boundary. Drill-hole and aquifer-test data are not available because a large part of the study area is in a protected, undeveloped wilderness area. Hydraulic characteristics were estimated mainly from geophysical data collected during the study. In addition, the hydraulic characteristics were compared with results from similar studies, with the assumption that this study area is hydrologically similar to other, more completely studied alluvial basins in southern Arizona. For the purpose of this report, the analysis focuses on the local flow system thought to supply water to the springs and the possible connection of this system with the system that is pumped for agricultural purposes in Mexico.

\section{Thickness and Continuity of Saturated Deposits}

The saturated thickness of the local flow system was estimated from seismic-refraction data to range from about 57 to $85 \mathrm{ft}$ (table 1 , lines 7, 8, and 9) along a 1-mile reach of Aguajita Wash (fig. 3). The base of the local aquifer is the low-permeable bedrock of fractured granite and is identified as layer 3 in table 1 . A small quantity of additional ground water probably is stored in the upper parts of the fractured granite bedrock, but the amount is unknown.

Inverse modeling of the gravity data was done for two sections to interpret boundaries between unsaturated and saturated deposits and consolidated rock (fig. 6). More than one structural cross section may be fit to a set of gravity responses, which causes a problem of nonunique solution. The problem of nonunique solution was constrained by applying interpreted depths to interfaces from seismic data, knowledge of the local geology, and values for densities on the basis of seismic velocities and average density for consolidated rock.

Seismic-refraction and gravity data collected parallel to the international boundary (fig. 2), combined with surficial geologic information, indicate that saturated sediments in the basin-fill deposits are interrupted in places by bedrock topographic highs (fig. 6). The bedrock highs are inferred to trend in a northeast-southwest direction on the basis of geologic outcrops. Geophysical data indicate that maximum depth to bedrock probably does not exceed $150 \mathrm{ft}$ between these outcrops (table 1, lines 3, 5, and 6, and fig. 6). Interpreted depth to bedrock does not exceed $20 \mathrm{ft}$ in the area where Aguajita Wash crosses the international boundary (fig. 6, section $B-B^{\prime}$ ). Interpreted depth to bedrock ranges from 0 to $100 \mathrm{ft}$ along the international boundary to about $2 \mathrm{mi}$ east of Aguajita Wash (fig. 6, section $B-B^{\prime}$ ). The altitude of the water table is about $1,035 \mathrm{ft}$ at Cerro Colorado Numero Dos, an area south of the international boundary near Rio Sonoyta where ground water is withdrawn for agriculture (fig. 5). Because the altitude of the water table is above the altitude of the bedrock in some locations on the 2-mile section east of Aguajita Wash along the international boundary (fig 6 , section $B-B^{\prime}$ ), it is inferred that continuity of saturated basin fill exists 

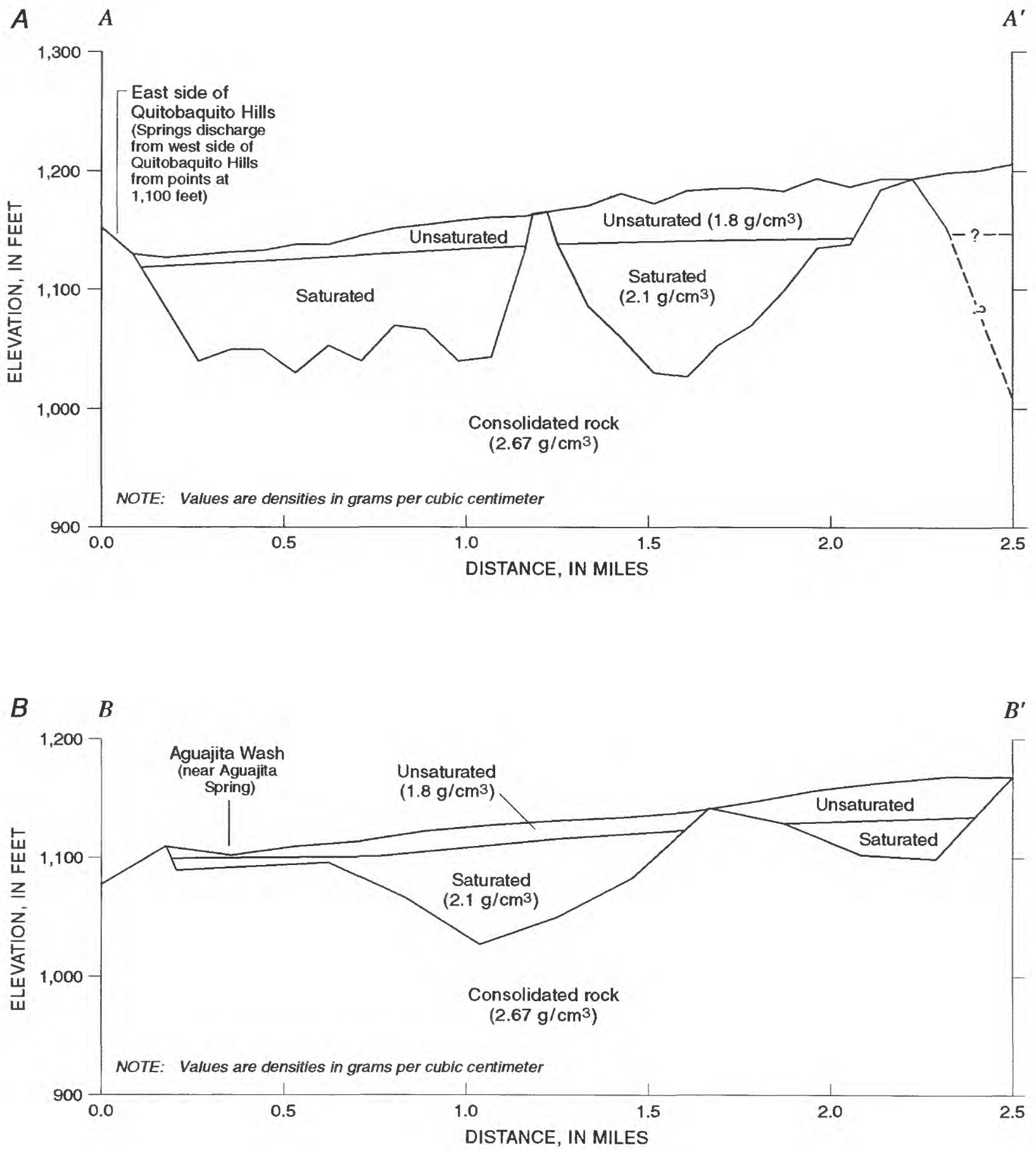

Figure 6. Interpretation of boundaries between unsaturated and saturated deposits and consolidated rock on the basis of gravity and seismic data. $A$, Section $A-A^{\prime}$. B, Section $B-B^{\prime}$. (See fig. 2.) 
between the well at Cerro Colorado Numero Dos and Aguajita Wash near the springs. Thus, a hydraulic connection may exist between the local flow system along Aguajita Wash and the regional flow system along the Rio Sonoyta. The irregular subsurface topography of the granitic bedrock may act locally as a flow barrier and, on a larger scale, as an impediment to ground-water flow between the flow system along Aguajita Wash and the ground-water flow system along the Rio Sonoyta. More detailed analysis of the subsurface bedrock topography south of the international boundary is needed to accurately evaluate the continuity of saturated basin fill in this area.

\section{Porosity, Hydraulic Conductivity, and Transmissivity}

Porosity of the alluvial deposits is the ratio of the volume of pore spaces to the total volume of material. Water in the aquifer occurs almost entirely in the pore spaces between the sedimentary particles. Hydraulic conductivity is the rate of flow of water through the interstices and is influenced by the degree of connection of the interstices. The transmissivity is equal to the average hydraulic conductivity multiplied by the saturated thickness of the aquifer.

Porosity, hydraulic conductivity, and transmissivity estimates were made for the local flow system along Aguajita Wash on the basis of geophysical data and available water-level information. An underlying assumption in this analysis is that this system is similar to other flow systems in southern Arizona and that a knowledge of the hydraulic characteristics of other basins can be transferred to the Quitobaquito Springs and La Abra Plain area with reasonable confidence.

The porosity is estimated to be 20 to 30 percent on the basis of observed seismic velocities and comparison with porosity values for basin-fill and stream-channel deposits in nearby alluvial basins. Hydraulic conductivities for the flow system along Aguajita Wash are estimated to range from 50 to more than $100 \mathrm{ft} / \mathrm{d}$ on the basis of comparison with conductivity values of similar saturated sediments in alluvial basins in south-central Arizona (Anderson and others, 1992). The transmissivity, which is based on the interpreted saturated thickness, is estimated to range from 2,800 to $8,500 \mathrm{ft}^{2} / \mathrm{d}$.

\section{CHEMICAL CHARACTER OF THE GROUND WATER}

Chemical analyses of water collected in 1976 by T.W. Anderson and R.L. Laney (USGS, written commun., 1978) from Bonita Well, Pozo Salado Well, and Quitobaquito Springs were re-evaluated with additional laboratory analyses of samples collected at the three sites in 1983 by the USGS. Chemical analyses of samples from Bonita Well, Pozo Salado Well, and Quitobaquito Springs (fig. 7) indicate that the major-ion chemistry is similar to the chemistry of ground water in other alluvial basins in southern Arizona (Robertson, 1991). The water from Bonita Well, which is upgradient from the springs, is a calcium bicarbonate type. The water contained $338 \mathrm{mg} / \mathrm{L}$ of dissolved solids and $0.4 \mathrm{mg} / \mathrm{L}$ of fluoride. The water type and relatively small concentrations of dissolved solids and fluoride in samples from Bonita Well are similar to Robertson's (1991) analyses of ground water sampled from recharge areas in alluvial basins in Arizona. In contrast, the water type and larger concentrations of dissolved solids and fluoride in samples from Pozo Salado Well and Quitobaquito Springs are similar to Robertson's analyses of ground water sampled from downgradient areas in alluvial basins in Arizona. The water from Pozo Salado Well and Quitobaquito Springs is a sodium bicarbonate chloride type. Dissolved-solids concentration in water from Pozo Salado Well was $1,500 \mathrm{mg} / \mathrm{L}$ and ranged from 662 to $783 \mathrm{mg} / \mathrm{L}$ in samples from Quitobaquito Springs. Fluoride concentrations increased downgradient to $4.4 \mathrm{mg} / \mathrm{L}$ in water from Quitobaquito Springs. The fluoride concentration was $5.4 \mathrm{mg} / \mathrm{L}$ in water from Pozo Salado Well.

The measured $\mathrm{pH}$ was 7.4 in water from Bonita Well and increased downgradient to 8.1 for Quitobaquito Springs. The measured $\mathrm{pH}$ was 8.4 in water from Pozo Salado Well. Robertson (1991) found that the $\mathrm{pH}$ of ground water increased downgradient in Vekol Valley, an alluvial basin with similar geology that is approximately $75 \mathrm{mi}$ northeast of La Abra Plain. Chemical reactions that 
Robertson modeled along a general flow path in Vekol Valley probably also occur in La Abra Plain between Bonita Well near the recharge area and Quitobaquito Springs, about $4.5 \mathrm{mi}$ downgradient. One dominant reaction is the precipitation of calcite, which causes the calcium concentration to decrease early along the flow path. Another reaction that may account for part of the calcium and sodium concentrations is ion exchange of calcium replacing sodium on the substrate. Robertson (1991) also noted that small concentrations of calcium can permit large fluoride concentrations under equilibrium conditions.

T.W. Anderson and R.L. Laney (USGS, written commun., 1978) found that the chemistry of the water from all the springs near Quitobaquito Hills is similar, indicating that the springs probably are connected to the same ground-water system. A carbon-14 analysis of the water sample collected in 1983 from Quitobaquito Springs indicates that the spring water probably is between 500 and several thousand years old. The relatively young age of the spring water indicates that the water is of local origin and probably originates as rainfall recharge along mountain-front areas north and northwest of La Abra Plain.

The similarity of relative compositions of water from Quitobaquito Springs and Pozo Salado Well (fig. 7) indicates that water in these downgradient areas flowed through areas with similar geohydrologic and geochemical characteristics and could have traveled along the same flow path. Bedrock outcrops east of the Quitobaquito Hills and shallow bedrock

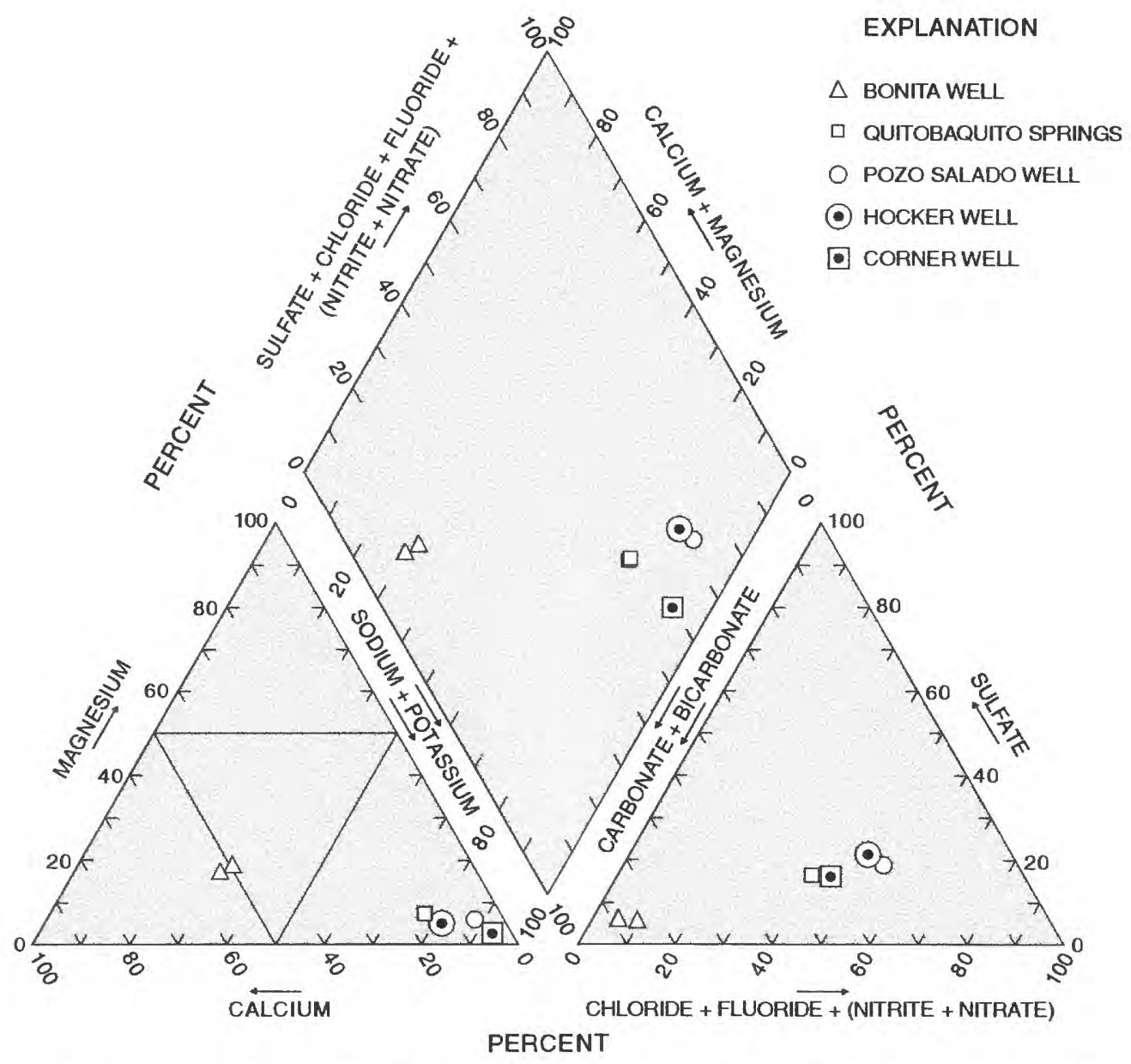

Figure 7. Relative compositions of ground water in the Quitobaquito Springs and La Abra Plain area, Arizona, in equivalent percents. (Locations of springs and wells shown in fig. 1.) 
interpreted from geophysical data, however, indicate that the water probably traveled along similar but divergent flow paths from recharge areas of similar geochemical characteristics.

\section{SPRING DISCHARGE AND RAINFALL}

Recommendations made in a reconnaissance study of the Quitobaquito Springs and La Abra Plain area (T.W. Anderson and R.L. Laney, USGS, written commun., 1978) included monitoring spring discharge and rainfall. The USGS, in cooperation with the National Park Service, began a monitoring program in October 1981 that continued through September 1992. Daily spring-discharge measurements were computed using data from instruments placed below the two principal spring openings that constitute Quitobaquito Springs. From October 1981 through December 1989, spring discharge was monitored downstream from the spring openings with an analog water-stage recorder and V-notch weir. Following a period of construction from January through April 1990, spring discharge was monitored with a digital water-stage recorder and Parshall flume until September 1992. In addition to the monitoring program, two rain gages were installed upgradient from the springs in the area of ground-water recharge (fig. 1). Discharge from Quitobaquito Springs ranged from 15 to $40 \mathrm{gal} / \mathrm{min}$ and averaged $28 \mathrm{gal} / \mathrm{min}$ for $1981-92$ (fig. 8). The variation in discharge with time may be partly explained by seepage between the spring-discharge points and the flume where discharge is measured and by the buildup and subsequent removal of phreatophytes by the National Park Service.

Rainfall at the two gages operated by the USGS in the area of recharge to the northeast of Quitobaquito Hills averaged $6.6 \mathrm{in} . / \mathrm{yr}$ for 1981-92; however, daily accumulations of rainfall exceeded 4 in. on two occasions (fig. 8). Data collected in the monitoring program during 1981-92, which represents the longest continuous period of record, were used to investigate the relation between rainfall in the upstream areas and flow to the springs. A time-series analysis was conducted to measure the strength of the rainfall-discharge relation. The sample correlation coefficient, $r$, between two variables, lies between
-1.0 and 1.0. An $r$ value near zero indicates no linear relation, and an $r$ near 1 indicates a positive linear relation. The correlation coefficient between monthly mean discharge at Quitobaquito Springs and total monthly rainfall was less than 0.2 and indicates that spring discharge is not highly correlated with local rainfall. To explore the possibility that periods of rainfall in the recharge area may affect future spring discharge, monthly lags were introduced to the cross correlation. For example, a lag of one would relate rainfall to discharge for the subsequent month. Lags of 1 month to 36 months did not produce a correlation that was statistically significant. Data from two rain gages operated by the National Park Service near Aguajita Wash and Quitobaquito Springs were not included in the analyses because of the short period of record. Rainfall at the two gages averaged 8.5 and 9.3 in./yr for 1988-92.

The statistical data indicate that local annual recharge probably is small relative to the total quantity of ground water in storage. Ground-water storage in the local flow system probably is sufficiently large to dampen the effect of recharge or dry periods on the discharge to the springs. This conclusion is supported by seismic-refraction data that indicate that the water-level altitude on the east side of Quitobaquito Hills is 15 to $50 \mathrm{ft}$ above the altitude of the spring-discharge points (fig. 6).

\section{WATER LEVELS IN AND ADJACENT TO THE STUDY AREA}

Water levels in the monument near the international boundary were recorded as part of the USGS monitoring program, which started in October 1981, expanded in December 1988, and concluded in September 1992. Water levels were measured on a bimonthly basis in Corner and Hocker Wells, along the international boundary west of the Quitobaquito Hills; Bonita and Pozo Salado Wells, in La Abra Plain; and Dowling, Stack, and Lukeville Wells, near the town of Lukeville (fig. 1). In addition, three monitoring wells were completed in December 1988 east of Lukeville to monitor water levels in the monument near expanding rural and agricultural areas in 

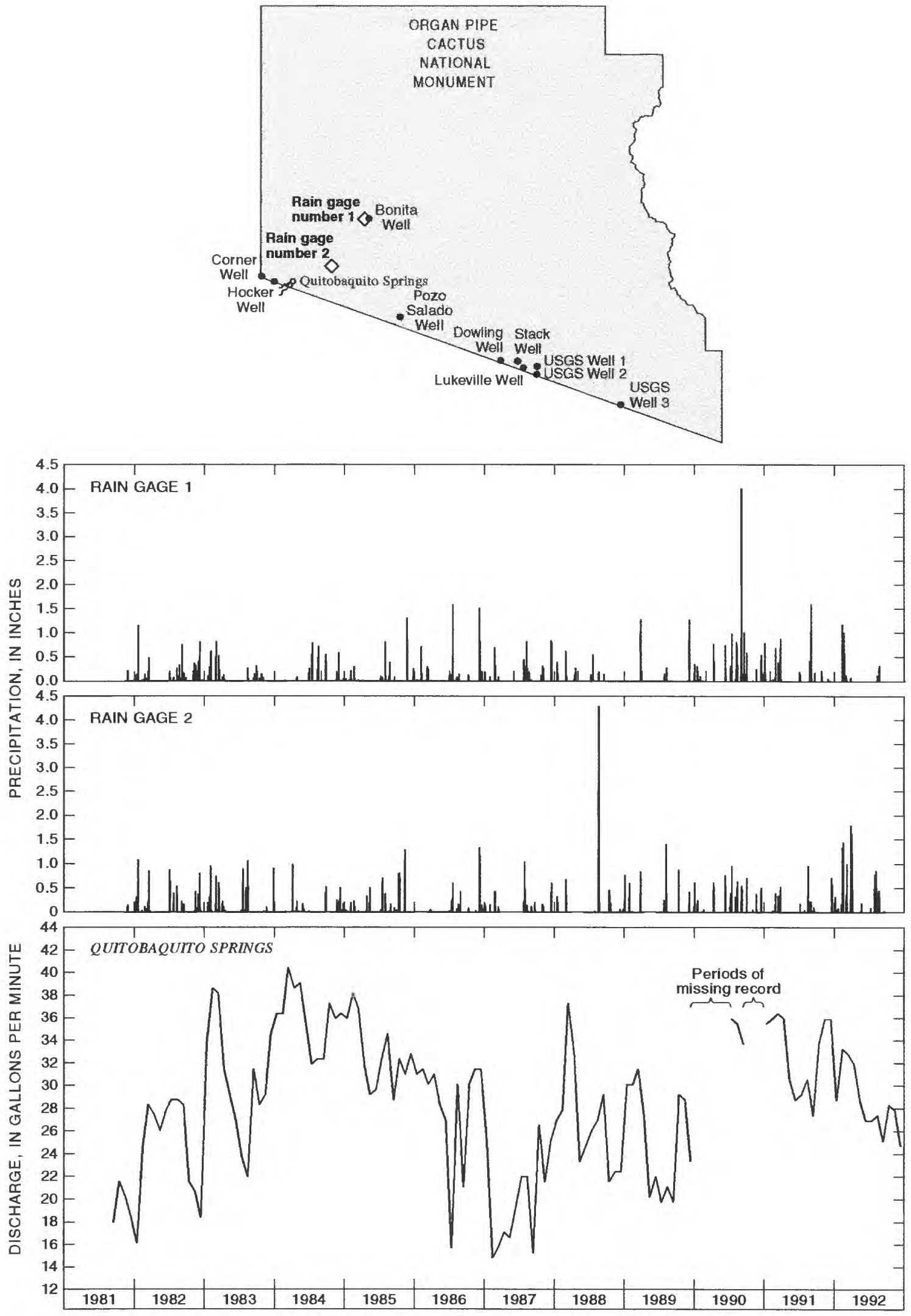

Figure 8. Total daily rainfall and mean monthly spring discharge in the Quitobaquito Springs and La Abra Plain area, Arizona, 1981-92. 
Sonora, Mexico (fig. 1). Bimonthly measurements continued through September 1992.

Depth to water at Bonita Well fluctuated within a range of about $10 \mathrm{ft}$ during the 11-year monitoring program and probably represents water-level conditions in the recharge area for the local ground-water system that supplies water to the springs (fig. 9). Water levels at Corner and Hocker Wells in the southwest corner of the monument varied 2 to $4 \mathrm{ft}$ during the monitoring program (fig. 9).
Depth to water in Pozo Salado Well, in the central part of La Abra Plain, probably represents ground-water conditions in the largest continuous body of saturated basin-fill deposits in the study area. Depth to water at Pozo Salado Well began to increase in about 1984 and continued to increase until October 1988 when the last successful measurement of $96 \mathrm{ft}$ was made (fig. 9).

The decline of water levels may be caused by ground-water withdrawals south of the international boundary. An attempt to obtain a
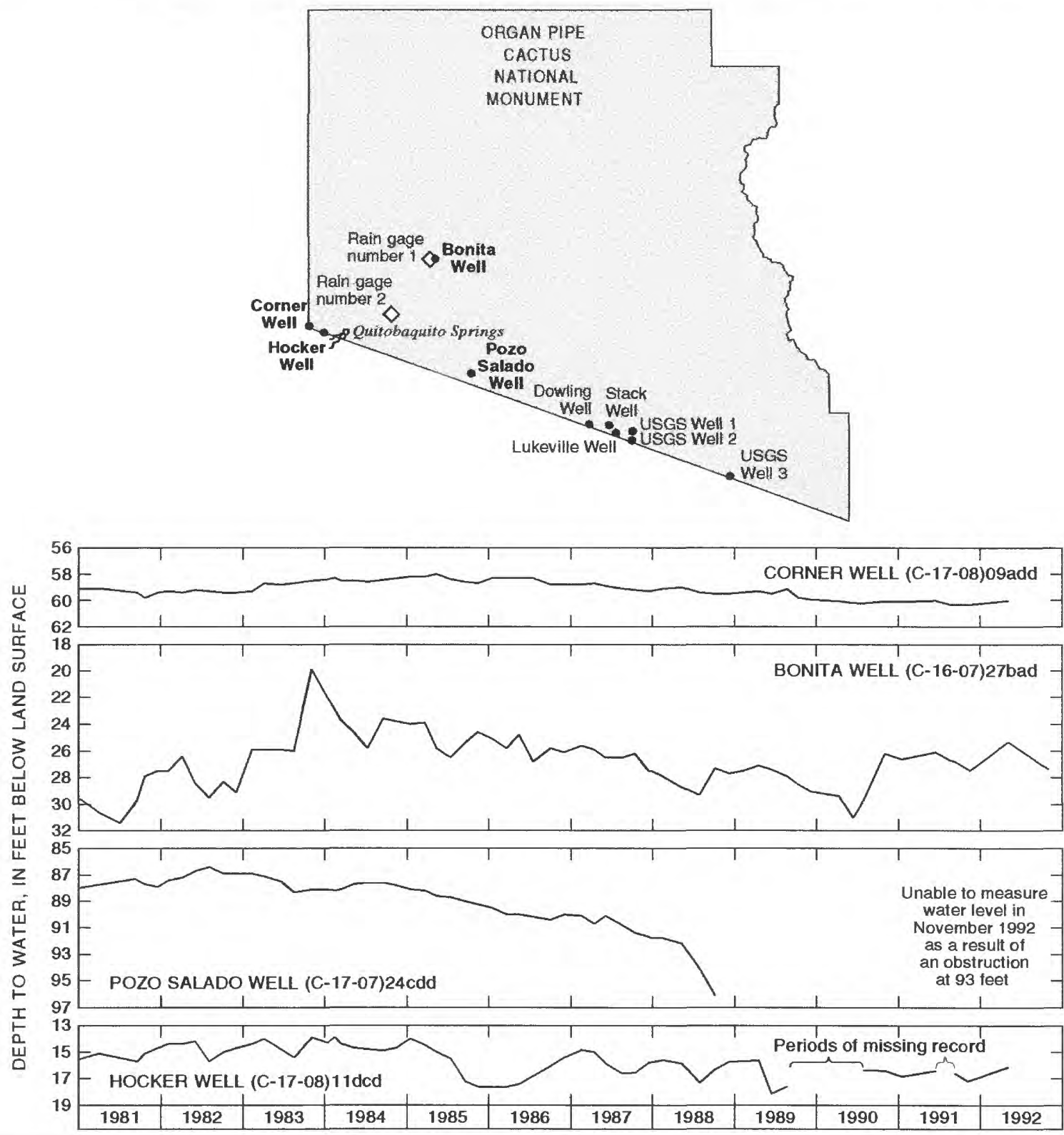

Figure 9. Ground-water levels in the Quitobaquito Springs and La Abra Plain area, Arizona, 1981-92. 
water-level measurement at Pozo Salado Well during this study was unsuccessful because of an obstruction at $93 \mathrm{ft}$. Additional water-level and pumping information on both sides of the international boundary are needed before any conclusions can be made about the effects of pumping in Mexico on water-level conditions in the central part of La Abra Plain.

Water levels at the Dowling, Stack, and Lukeville Wells declined about 1 to $7 \mathrm{ft}$ for the 11-year monitoring program (fig. 10). The declines may be a result of increased pumping in Lukeville and the adjacent town of Sonoyta, Mexico. Water-level records for the three monitoring wells completed in December 1988 are too brief to provide significant information on water-level trends (fig. 10). Periodic measurements at all the wells in the monitoring program may need to be continued. In addition, close monitoring of water levels in wells near Lukeville and an attempt to clear the obstruction in Pozo Salado Well may need to be considered.

\section{CONCEPTUAL MODEL OF THE LOCAL FLOW SYSTEM}

A conceptual model of the movement of ground water and the geometry of the aquifer system that provides water to the springs will assist personnel of Organ Pipe Cactus National Monument in the management and protection of water resources. The local flow system along Aguajita Wash that provides water to the springs consists mainly of saturated porous sediments. The local aquifer system also includes some water that is stored and transmitted within the upper zone of the fractured granitic rocks. For the purposes of the water-budget analysis, estimated boundaries for the local flow system include the Quitobaquito Hills to the west of Aguajita Wash and bedrock outcrops and shallow bedrock to the east. The quantity of ground water that enters, moves through, discharges through springs, and leaves the system probably is small relative to the total volume in storage.

The main source of ground-water recharge to the local flow system is the infiltration of runoff through the basin-fill deposits along the mountain fronts in the northwestern part of La Abra Plain. Additional recharge occurs through the stream-channel deposits of Aguajita Wash. Fractures in the upper zone of the consolidated rocks probably allow a minor amount of runoff to infiltrate and recharge the ground-water system. No ground water is assumed to enter the system from adjacent basins. Ground water moves southward through the local flow system to the area of shallow bedrock near Aguajita Spring and the international boundary. Fractures in the granitic intrusive rocks near a northwestward-trending high-angle fault provide conduits for ground water to flow to a line of springs on the southwest side of Quitobaquito Hills and to Aguajita Spring near the international boundary. Ground water also leaves the system through fingers of alluvium between bedrock outcrops near the international boundary.

\section{Ground-Water Budget}

Estimates for a ground-water budget or an accounting of the inflow to and outflow from the local aquifer and changes in ground water in storage were made using available data. For this model, the local aquifer is assumed to be in equilibrium or steady state condition - inflow equals outflow - and the change in the volume of water in storage is zero.

The primary inflow to the local flow system is recharge from the infiltration of rainfall. Most of the infiltration is thought to occur through the basin-fill and stream-channel deposits that cover the pediments along the mountain fronts. The average rainfall in the recharge area was about $6.6 \mathrm{in} . / \mathrm{yr}$ for the 11-year monitoring program. Using a rainfall-altitude-location relation, an estimated 5 to 10 percent of the rainfall recharged the local flow system in the study area (Wilson and others, 1980). Recharge from about $25 \mathrm{mi}^{2}$ of mountains and alluvium-covered pediment within the boundary of the local flow system (fig. 5) is estimated to range from 50,000 to $100,000 \mathrm{ft}^{3} / \mathrm{d}$. A conservative estimate of $50,000 \mathrm{ft}^{3} / \mathrm{d}$ of inflow is used in water-budget calculations. By definition, the local flow system is in steady state, thus 50,000 $\mathrm{ft}^{3} / \mathrm{d}$ is used in water-budget calculations for outflow, or discharge from the system. Using the estimated value for discharge from the local flow 

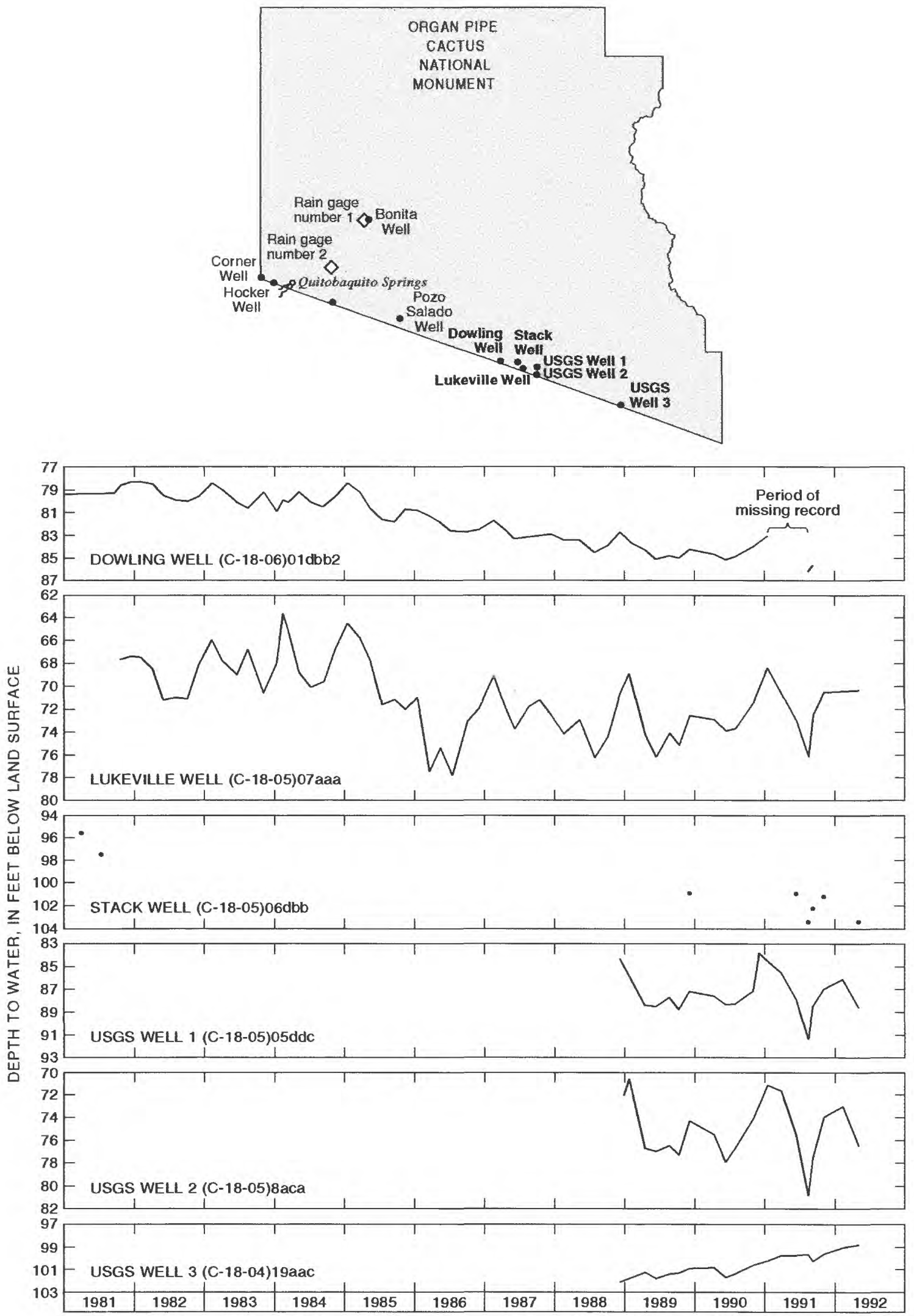

Figure 10. Ground-water levels in the Lukeville area of Organ Pipe Cactus National Monument, 1981-92. 
system, hydraulic conductivity is estimated using Darcy's Law:

$$
Q=K I A,
$$

where:

$$
\begin{aligned}
& Q= \text { discharge, in cubic feet per day; } \\
& K= \text { hydraulic conductivity, in feet per } \\
& \text { day; }
\end{aligned}
$$

The hydraulic conductivity is estimated to be about $75 \mathrm{ft} / \mathrm{d}$ on the basis of hydraulic conductivities of similar sediments (Anderson and others, 1992). Values for the remaining variables in the Darcy's Law calculation are a hydraulic gradient of $0.008 \mathrm{ft} / \mathrm{ft}(40 \mathrm{ft} / \mathrm{mi})$ and a cross-sectional area of flow of $82,500 \mathrm{ft}^{2}$ (width of $1,500 \mathrm{ft}$ and saturated thickness of $55 \mathrm{ft}$ ). The value for hydraulic gradient was derived from known and interpreted water levels. The value for cross-sectional area of flow was computed from a flow-net analysis of the local flow system and on estimated saturated thickness for the basin fill.

Outflow from the local flow system occurs as underflow through the fingers of alluvium near Aguajita Wash and the international boundary, as discharge to springs, and as consumptive use by riparian vegetation along Aguajita Wash. Outflow of ground water through the alluvium near the international boundary, discharge to springs, and transpiration by riparian trees, are defined to be the quantity of water equal to the inflow to the local flow system. An unknown amount of ground-water withdrawals by wells near the international boundary also may be a component of outflow.

Discharge from Quitobaquito Springs is about $5,500 \mathrm{ft}^{3} / \mathrm{d}$. Discharge from Quitobaquito Springs combined with the other springs is estimated to be $6,000 \mathrm{ft}^{3} / \mathrm{d}$. Consumptive use by riparian vegetation along Aguajita Wash was estimated using a relation between depth to ground water and annual water use (Anderson, 1976). Along Aguajita Wash to the east of Quitobaquito Hills, approximately 50 acres are covered by mesquite and ironwood trees, and the depth to water is from 15 to $20 \mathrm{ft}$, which corresponds to an annual water use of about 25 in. or about $10,000 \mathrm{ft}^{3} / \mathrm{d}$. The remaining $34,000 \mathrm{ft}^{3} / \mathrm{d}$ of inflow leaves the local flow system as underflow through the fingers of alluvium along the international boundary, as discharge to wells, or as fracture flow. Interpreted cross sections for the fingers of alluvium, the hydraulic gradient of 0.008 , and equation 1 were used to verify the steady-state underflow out of the system.

The quantity of ground water in storage in the local flow system is constant as shown by the absence of long-term increases or decreases in spring discharge or rises or declines in water levels (fig. 8, 9, and 10). The total amount of ground water in storage within the local flow system is estimated to be about 30 times the annual inflow of $50,000 \mathrm{ft}^{3} / \mathrm{d}$ on the basis of the cross-sectional area of flow used in the Darcy's Law calculation, a length of $5 \mathrm{mi}$, and a porosity of 0.25 . The total quantity of ground water in storage above the discharge altitude of the springs is estimated to be about 90 times the combined annual discharge of $6,000 \mathrm{ft}^{3} / \mathrm{d}$ for the springs on the basis of a cross-sectional area of $30,000 \mathrm{ft}^{2}(1,500 \mathrm{ft}$ wide by a saturated thickness of $20 \mathrm{ft}$ ), a length of $5 \mathrm{mi}$, and a porosity of $\mathbf{0 . 2 5}$. The estimates for the groundwater budget were made to expand conceptual knowledge of the flow system that provides water to the springs with the realization that errors are inherent in the methods used to estimate the values.

\section{EFFECTS OF GROUND-WATER WITHDRAWALS}

On the basis of the monitoring program, water-chemistry data, and geophysical data, the thin saturated alluvium that overlies shallow crystalline rocks in the northwestern part of La Abra Plain is interpreted to represent a local flow system that is part of a larger regional ground-water system along the Rio Sonoyta. Discharge at the series of springs represents a part of the outflow from the local flow system, which is a small ground-water basin that extends to the northeast of Quitobaquito Hills and encompasses 
about $25 \mathrm{mi}^{2}$. The entire recharge area for the local flow system that provides water to the springs is within Organ Pipe Cactus National Monument.

Discharge at the springs could be reduced by development within the recharge area of the local flow system. Present (1993) rates of ground-water withdrawals south of the international boundary do not appear to affect water-level conditions in the local flow system or discharge to the springs. The altitude of the granite bedrock near the international boundary indicates a hydraulic connection may exist between the local flow system and the regional flow system along the Rio Sonoyta. The irregular subsurface topography of the bedrock, however, may provide a semicontinuous barrier to and (or) delay the effect of a northwest propagation of water-level declines caused by pumping near the Rio Sonoyta.

Increased pumping in Mexico may affect water levels in the ground-water system in the central part of La Abra Plain. If future pumping rates along the Rio Sonoyta greatly exceed present rates, it may be possible for the pumping effect to propagate through the central part of La Abra Plain and reach the recharge area for the local flow system; however, this effect is poorly understood because of the few data that are available. Monitoring of water levels on both sides of the international boundary and pumpage quantities in Mexico needs to be continued to provide information on water-level conditions in the study area. In addition, more detailed analysis of subsurface bedrock topography on both sides of the international boundary is needed to evaluate the continuity of the saturated basin fill in the study area.

\section{SUMMARY AND CONCLUSIONS}

This hydrogeologic study was done to define the ground-water flow system in the Quitobaquito Springs and La Abra Plain area, to develop a conceptual model of the flow system that provides water to the springs, and to evaluate the possibility that the natural flow from Quitobaquito Springs might be reduced by ground-water withdrawals in the adjacent State of Sonora, Mexico. Results of the study indicate that a small ground-water flow system, upgradient and somewhat isolated from the flow system along the Rio Sonoyta in Mexico, exists along the Aguajita Wash drainage and provides a source of water to the springs.

The study area encompasses about $100 \mathrm{mi}^{2}$ and is bounded by low, jagged, basin-bounding mountains to the north, east, and west, and by the Rio Sonoyta to the south. The area receives about $6.6 \mathrm{in} . / \mathrm{yr}$ of rainfall, most of which evaporates or is transpired by plants. About 5 to 10 percent of the rainfall infiltrates sediments along the mountain fronts and the stream-channel deposits to become ground-water recharge. Water-level, geophysical, and water-chemistry data indicate that ground-water flow parallels the direction of surface-water drainage in at least the west half of the study area. The largest continuous body of saturated basin-fill deposits probably extends from the central part of $\mathrm{La}$ Abra Plain to the ground-water system along the Rio Sonoyta.

To the east of Quitobaquito Hills, a mantle of alluvial-fan deposits covers the shallow crystalline rocks and interfingers with the stream-channel deposits of Aguajita Wash. Ground-water recharge through and storage within these deposits make up the local flow system that provides water to the springs. The local aquifer system also includes some water that is stored and transmitted within the upper zone of the fractured granitic rocks. The recharge area for the local flow system encompasses approximately $25 \mathrm{mi}^{2}$ and is entirely within the Organ Pipe Cactus National Monument.

The chemistry of the water from all the springs is similar. The carbon-14 analysis of a water sample from Quitobaquito Springs indicates that the spring water probably is of local origin and is between 500 and several thousand years old. The water type and relatively small concentrations of dissolved solids and fluoride in samples from Bonita Well are similar to those of ground water sampled in recharge areas in other alluvial basins in Arizona. In contrast, the water type and larger concentrations of dissolved solids and fluoride in samples from Pozo Salado Well and Quitobaquito Springs are similar to those of ground water sampled in downgradient areas in other alluvial basins in Arizona. The location of bedrock outcrops and shallow bedrock interpreted from geophysical data support the conclusion that the water probably traveled along similar but divergent 
flow paths from recharge areas of similar geochemical characteristics.

Discharge from Quitobaquito Springs averaged $28 \mathrm{gal} / \mathrm{min}$ for $1989-92$. Rainfall at two gages in the area of ground-water recharge averaged $6.6 \mathrm{in} . / \mathrm{yr}$ for 1981-92; however, on two occasions, 24-hour accumulations of rainfall exceeded 4 in. A correlation conducted to measure the strength of the rainfall-discharge relation produced an $r$ value of less than 0.2 , indicating that spring discharge is not highly correlated with local rainfall. The statistical data are consistent with the conclusion that local annual recharge probably is small relative to the total quantity of ground water in storage. The ground-water storage in the local flow system probably is sufficiently large to dampen the effect of recharge or dry periods on the discharge from the springs.

Ground water moves southward through the local flow system along Aguajita Wash toward the area of shallow bedrock near the international boundary. Fractures in the granitic intrusive rocks provide conduits for ground water to flow to springs on the southwest side of Quitobaquito Hills. Annual recharge from about $25 \mathrm{mi}^{2}$ of mountains and alluvium-covered pediment within the boundary of the local flow system is estimated to range from 50,000 to $100,000 \mathrm{ft}^{3} / \mathrm{d}$. The hydraulic gradient is estimated to be $0.008 \mathrm{ft} / \mathrm{ft}$ between Bonita Well and Aguajita Wash, and the hydraulic conductivity is estimated to be about $75 \mathrm{ft} / \mathrm{d}$. Seismic-refraction data indicate that the saturated thickness ranges from 57 to $85 \mathrm{ft}$ along Aguajita Wash for at least a 1-mile section adjacent to Quitobaquito Hills before shallow bedrock is encountered near Aguajita Spring. The transmissivity is estimated to range from 2,800 to $8,500 \mathrm{ft}^{2} / \mathrm{d}$.

The quantity of ground water in storage in the local flow system probably is constant as evidenced by the absence of long-term trends of increased or decreased spring discharge or rising or declining water levels. The total amount of ground water in storage within the local flow system is estimated to be about 30 times the annual inflow of $50,000 \mathrm{ft}^{3} / \mathrm{d}$. Interpreted geophysical data indicate that a head of 15 to $50 \mathrm{ft}$ exists upgradient from the spring-discharge points. The total quantity of ground water in storage above the discharge altitude of the springs is estimated to be about 90 times the combined annual discharge of $6,000 \mathrm{ft}^{3} / \mathrm{d}$ for the springs.

Discharge at the springs could be reduced by development within the recharge area for the local flow system. Present (1993) rates of ground-water withdrawals south of the international boundary, however, do not appear to affect water-level conditions in the local flow system or discharge to the springs. The altitude of the granite bedrock near the international boundary indicates a hydraulic connection may exist between the local flow system providing water to the springs and the regional flow system along the Rio Sonoyta. An irregular subsurface topography of the relatively low permeable granite bedrock near the international boundary, however, may provide a semicontinuous barrier to and (or) delay the effect of a northwestward propagation of water-level declines caused by pumping near the Rio Sonoyta. More subsurface topographic data are needed to evaluate the continuity of the hydraulic connection.

Increased pumping in Mexico may affect water levels in the ground-water system in the central part of La Abra Plain. If future pumping rates along the Rio Sonoyta greatly exceed present (1993) rates, it might be possible for the pumping effect to propagate through the ground-water system in central La Abra Plain and reach the recharge area for the local flow system. Monitoring of water levels on both sides of the international boundary and pumpage quantities in Mexico are needed to provide a better understanding of the hydrologic conditions in the study area. In addition, in order to provide current information along the greater monument boundary area with Mexico, periodic water-level measurements may need to be continued at all the wells in the monitoring program.

\section{SELECTED REFERENCES}

Anderson, T.W., 1976, Evapotranspiration losses from flood-plain areas in central Arizona: U.S. Geological Survey Open-File Report 76-864, 91 p.

Anderson, T.W., Freethey, G.W., and Tucci, Patrick, 1992, Geohydrology and water resources of alluvial basins in south-central Arizona and parts of adjacent States: U.S. Geological Survey Professional Paper 1406-B, $67 \mathrm{p}$. 
Damon, P.E., Lynch, D.J., and Shafiqullah, M., 1984, Cenozoic landscape development in the Basin and Range province of Arizona, in Smiley, T.L., Nations, J.D., Péwé, T.L., and Schafer, J.P., eds., Landscapes of Arizona-The geological story: Lanham, Maryland, University Press of America, chap. 9, p. 175-203.

Fenneman, N.M., 1931, Physiography of the Western United States: New York, McGraw-Hill, 534 p.

Gray, F., Miller, R.J., Grubensky, M.J., Tosdal, R.M., Haxel, G.B., Peterson, D.W., May, D.J., and Silver, L.T., 1988, Geologic map of the Ajo and Lukeville $1^{\circ}$ by $2^{\circ}$ quadrangle, southwest Arizona: U.S. Geological Survey Open-File Report 87-347, 23 p.

Haxel, G.B., Tosdal, R.M., May, D.J., and Wright, J.E., 1984, Latest Cretaceous and early Tertiary orogenesis in south-central Arizona-Thrust faulting, regional metamorphism, and granitic plutonism: Geological Society of America, June 1984 , v. 94 , p. $631-653$.
Hollett, K.J., 1985, Geohydrology and water resources of the Papago Farms-Great Plain area, Papago Indian Reservation, Arizona, and the Upper Rio Sonoyta area, Sonora, Mexico: U.S. Geological Survey Water-Supply Paper 2258, 44 p.

Hollett, K.J., and Marie, J.R., 1987, Simulation of the ground-water flow system and proposed withdrawals in the northern part of Vekol Valley, Arizona: U.S. Geological Survey Water-Resources Investigations Report 86-4340, 68 p.

Organ Pipe Cactus National Monument, 1992, Water resources management plan: U.S. Department of the Interior, National Park Service, 138 p.

Robertson, F.N., 1991, Geochemistry of ground water in alluvial basins of Arizona and adjacent parts of Nevada, New Mexico, and California: U.S. Geological Survey Professional Paper 1406-C, $90 \mathrm{p}$.

Wilson, L.G., DeCook, K.J., and Newman, S.P., 1980, Regional recharge research for southwest alluvial 